\title{
INVESTIGATION OF THE REMOVAL OF ASH, SULPHUR AND OTHER CONTAMINANTS FROM COAL BY WET MAGNETIC SEPARATION
}

\author{
V.I. KARMAZIN, YU. S. MOSTIKA AND E.N. SAVLUK \\ The State Mining Academy of Ukraine, 320014 Dnepropetrovsk, Ukraine
}

(Received August 18, 1993, revised March 14, 1994)

\begin{abstract}
This paper presents the results of wet magnetic beneficiation of finely ground coals by high-gradient magnetic separation, with the aim to remove deleterious and toxic impurities.
\end{abstract}

\section{INTRODUCTION}

Power stations that use solid fuel are the primary source of atmospheric pollution by sulphur gases and by other detrimental and toxic components. The purification of coal, before it is burned, is one of the ways how to reduce emission into the atmosphere.

In coals from the Donetsk Basin sulphur appears in the form of fine pyrite with particle size 50 to $100 \mu \mathrm{m}$ or less which causes low efficiency of gravitational techniques of coal desulphurisation.

High-gradient magnetic separation (HGMS) allows to recover feebly magnetic particles of sizes down to several micrometers and it presently appears to be the most promising method of coal desulphurisation.

A developing factor in the research investigation of coal desulphurisation is the absence of data on magnetic properties of various coals and of minerals present in 
these coals. This paper will present some results of investigation of properties of various types of coal and principles of their beneficiation and desulphurisation by HGMS before their burning in the form of water-based slurry.

\section{THE CHARACTERISTICS OF THE SAMPLES}

\section{Composition of Samples}

Representative samples from four large Ukrainian power stations were investigated. The fuel used in the first power station were the anthracite fines and partly an intermediate product from the anthracite beneficiation (A). In the second power station the low-grade run-of-mine coal and the preparation concentrate $(T)$ were used while in the third power station the run-of-mine gas coal and long-flame coals were used (GD). The fourth power station burns the slimes from preparation plants-reprocessed coal from the Donbass mines (D).

In all of these power stations the coal is pulverised to $90 \%-100 \mu \mathrm{m}$ and then burned in a dry form. Table I summarises the characteristics of coals burned in the above mentioned four power power stations. Granulometric analysis of one of the samples, together with distribution of ash and sulphur in different size fractions are given in Table II.

Investigation of coals of different classes and different form in which the sulphur-containing minerals are present has shown that sulphur is associated with sulphides, organic compounds, sulphates and it can also appear in elementary form. The sulphide sulphur is generally present as pyrite and represents 60 to $70 \%$ of total sulphur in the samples.

Organic sulphur is a part of the chemical structure of a coal and cannot be removed by physical means. The sulphate sulphur which is present in concentration not exceeding 0.1 to $0.5 \%$ occurs in oxidised varieties of coal and is represented mainly by gypsum and iron sulphates. The elementary sulphur is present in very low concentrations 0.03 to $0.15 \%$ and is confined to oxidised coals. 
Table I The characteristics of coals burned in major power stations in Ukraine

\begin{tabular}{||c|c|c|c|c|c||}
\hline Power station & Coal grade & $\begin{array}{c}\text { Tonnage of } \\
\text { coal burned, } \\
\text { mil. tons }\end{array}$ & $\begin{array}{c}\text { Power station } \\
\text { output/no. of } \\
\text { boilers, MW }\end{array}$ & $\begin{array}{c}\text { Mean ash } \\
\text { content (\%) }\end{array}$ & $\begin{array}{c}\text { Mean total } \\
\text { sulphur (\%) }\end{array}$ \\
\hline 1 & $\begin{array}{c}\text { Antracite } \\
\text { fines, A }\end{array}$ & 3,0 & $4 / 400$ & 24,0 & 1,8 \\
\hline 3 & $\begin{array}{c}\text { Run-of-mine } \\
\text { coal and } \\
\text { preparation } \\
\text { concentrate, T }\end{array}$ & 6,5 & $10 / 950$ & 27,5 & 2,4 \\
\hline 4 & $\begin{array}{c}\text { Run-of-mine } \\
\text { gas coal and } \\
\text { long-flame } \\
\text { coal, GD }\end{array}$ & 2.5 & $4 / 300,3 / 800$ & 38.0 & 2,5 \\
\hline $\begin{array}{c}\text { Slimes from } \\
\text { reprocessed } \\
\text { Donbass coal, } \\
\text { D }\end{array}$ & 4.7 & $8 / 300$ & 40,0 & 2,5 \\
\hline
\end{tabular}

Table II The sedimentation analysis of a pulverised low-grade coal. $\mathrm{A}^{\mathrm{d}}$-concentration of ash, $\mathrm{S}^{\mathrm{d}}$-concentration of total sulphur, $\mathrm{R}_{\mathrm{A}}$-recovery of ash.

\begin{tabular}{|c|c|c|c|c|}
\hline $\begin{array}{c}\text { Particle size } \\
(\mathrm{mm})\end{array}$ & $\begin{array}{c}\text { Mass distribution } \\
(\%)\end{array}$ & $\mathrm{A}^{\mathrm{d}}(\%)$ & $\mathrm{S}^{\mathrm{d}}(\%)$ & $\mathrm{R}_{\mathrm{A}}(\%)$ \\
\hline+2.5 & 2.4 & 54,9 & 2.84 & 5,7 \\
$1,6-2.5$ & 2,8 & 46,0 & 3,38 & 5,6 \\
$1.0-1.6$ & 14,3 & 36,2 & 3.52 & 22,3 \\
$0.63-1.0$ & 3,1 & 18,0 & 3.02 & 2,4 \\
$0,4-0.63$ & 18,5 & 19,0 & 3.18 & 15.2 \\
$0.2-0.4$ & 21,8 & 14,6 & 3.03 & 13,7 \\
$0,1-0,2$ & 12,4 & 17,1 & 3.24 & 9,1 \\
$0,063-0.1$ & 6.7 & 16,6 & 3.52 & 4,8 \\
$0,038-0.063$ & 3,6 & 22,5 & 4.01 & 3,3 \\
-0.038 & 14,4 & 28,8 & 2.23 & 17.9 \\
Feed & 100.0 & 23.2 & 3.28 & 100.0 \\
\hline
\end{tabular}


Magnetic properties of coal of different grades were investigated using representative samples of coal and samples of fuel from power stations. The force method was employed to measure specific magnetic susceptibility using an apparatus designed to measure standard samples of magnetic susceptibility of diamagnetic and paramagnetic materials. The apparatus is a standard facility for the measurement of specific magnetic susceptibility in the range from $1 \times 10^{-7}$ to $1 \times 10^{-3} \mathrm{~m}^{3} / \mathrm{kg}$. Specific magnetic susceptibilities of the original and purified coals were measured by the Guoy method while the Faraday method was used to measure samples of magnetic fractions.

Figure 1 depicts the dependence of specific magnetic susceptibility of coal as a function of its density. It transpired that the coal fractions with density smaller than $1.4 \mathrm{~g} / \mathrm{cm}^{3}$ had clearly pronounced diamagnetic properties.

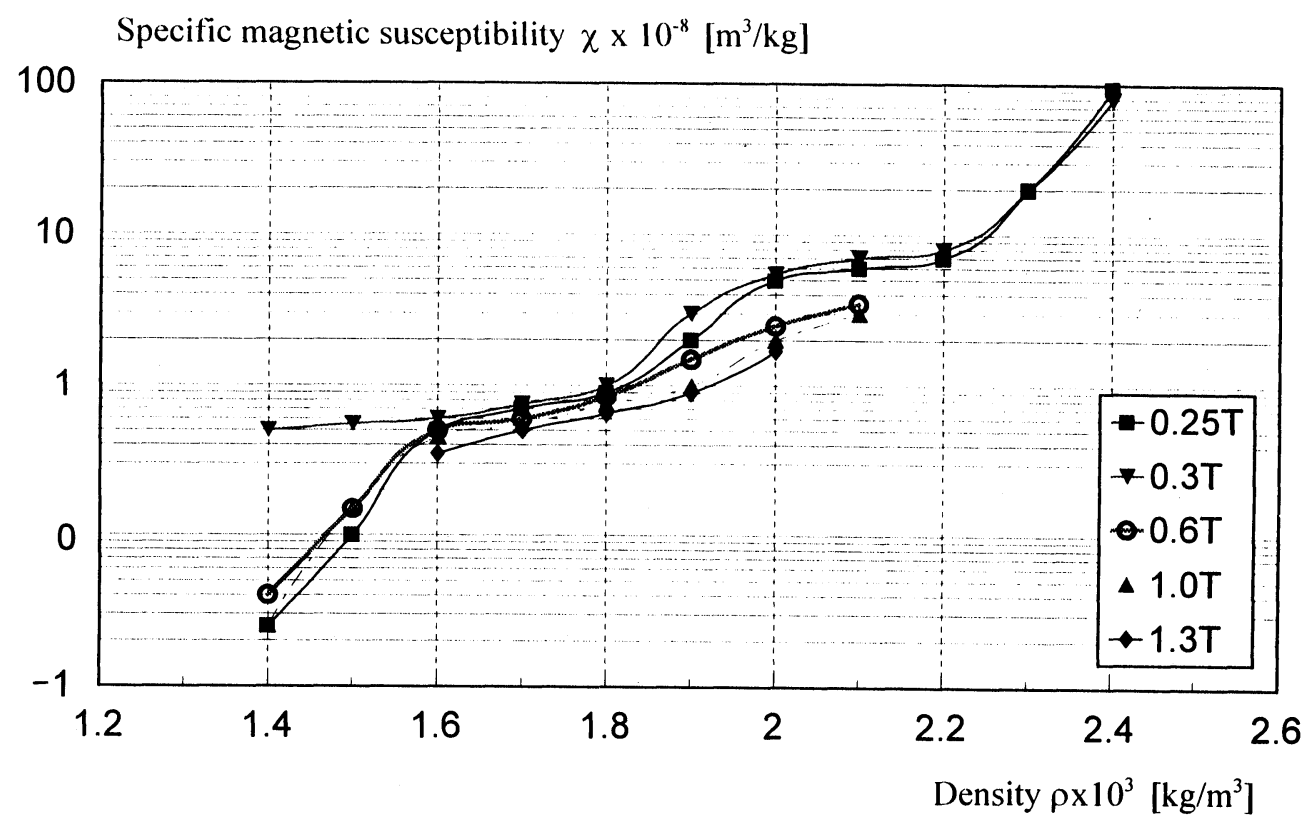

Fig 1. Specific magnetic susceptibility $\chi$ of coal as a function of density $\rho$ of fractions 
In spite of low magnetic susceptibility of coal, substantial differences in magnetic properties of coal and rock particles indicate a possibility of separation of the organic fraction of coal from mineral components by the magnetic means.

Specific magnetic susceptibility of coal depends on the magnetic field strength at which the measurements are carried out. It indicates the presence of ferromagnetic admixtures in the coal samples (Figure 2).

The investigation of specific magnetic susceptibility of samples has shown that coal has different magnetic properties, depending on the degree of metamorphism. The coal grades GD are basically diamagnetic (as a result of oxidation, the magnetic susceptibility of the mineral component is reduced). The coal grades $\mathbf{T}$ and $\mathbf{A}$, with a high stage of metamorphism have paramagnetic properties and are characterised by an intermediate contrast of magnetic properties.

Thirty three elements were investigated in the samples: total sulphur and sulphur according to its chemical form, and also arsenic, germanium and gallium were determined by chemical techniques, mercury was determined by atomic absorption, fluorine by spectrometric quantitative analysis, rubidium and cesium by flame photospectrometry, lithium and other elements by semiquantitative spectrometric analysis (Table III).

\section{MAGNETIC BENEFICIATION OF COAL}

Research into the beneficiation and purification of pulverised coal by wet high-gradient magnetic separation was carried out in laboratory magnetic separators with horizontal and vertical directions of the magnetic field, and in SALA laboratory magnetic separator.

These laboratory separators allow to perform experiments at magnetic induction up to 2 Tesla, with various types of matrices, namely grooved plates, expanded metal, steel balls and steel wool, of various dimensions and shapes. The experimental procedure was as follows: 


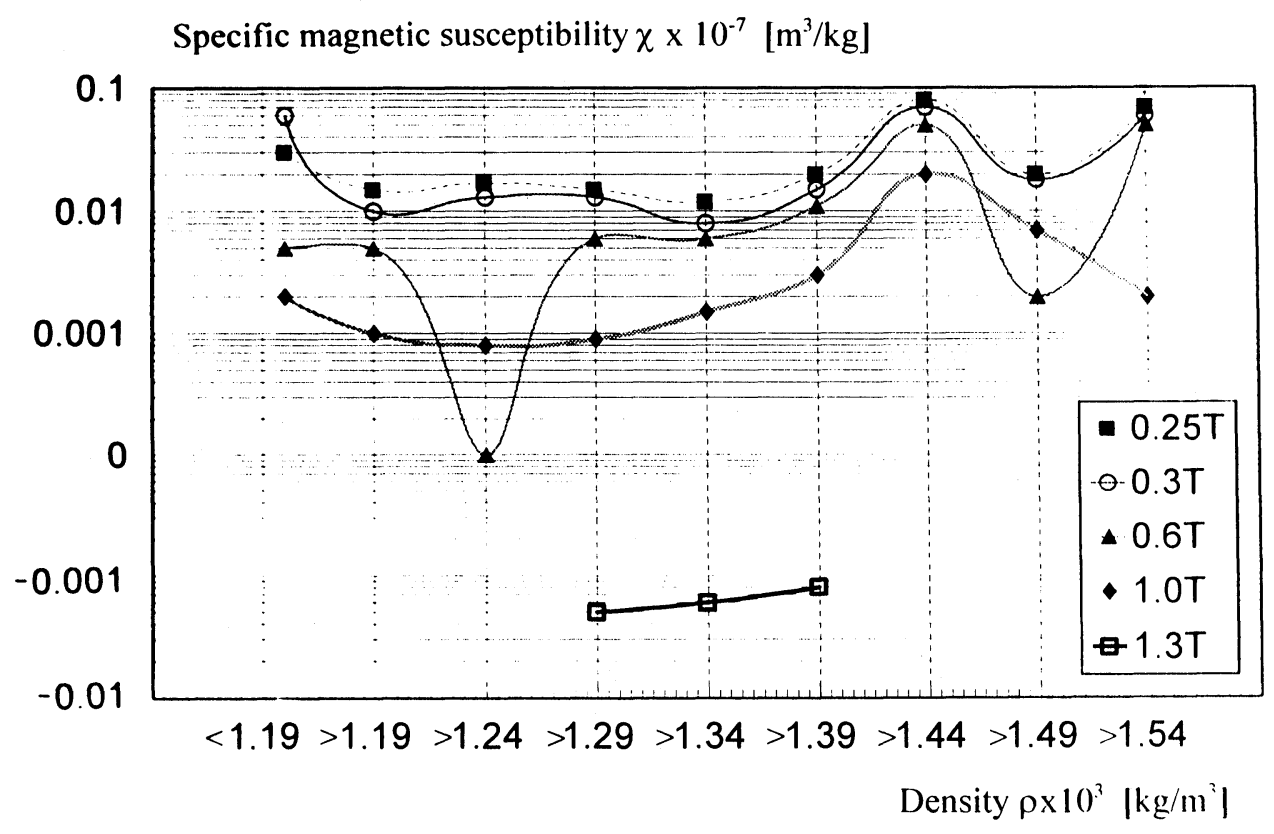

Fig. 2 Magnetic susceptibility of coal $\mathrm{T}$ as a function of magnetic induction and density of the fractions.

1. A sample was prepared and then suspended in water

2. The slurry was then passed through a magnetic separator under well-defined experimental conditions, with various matrices

3. The matrix was rinsed in direct or reverse directions

4. The magnetic product was flushed from the matrix in the direct or reverse directions, with magnetic field switched off.

The effect of the following parameters, on technological indices of coal purification by HGMS, was investigated: magnetic induction, flow velocity of the slurry, matrix loading, slurry density and others.

Figures 3, 4, 5 and 6 depict some characteristic dependencies which illustrate the degree of influence of various parameters on the efficiency of the beneficiation of coal. 
COAL DESULPHURISATION BY HGMS

Table III Distribution of accompanying elements in the coal feed

\begin{tabular}{|c|c|c|c|c|}
\hline \multirow[b]{2}{*}{ Element } & \multicolumn{4}{|c|}{ Concentration of elements $(\mathrm{g} / \mathrm{t})$} \\
\hline & $\mathrm{A}$ & $\mathrm{T}$ & GD & $\mathrm{D}$ \\
\hline As & 17.2 & 12,7 & 18,44 & 20,71 \\
\hline $\mathrm{F}$ & 109.1 & 132,0 & 86,24 & 141,35 \\
\hline $\mathrm{Hg}$ & - & 0.152 & 0.20 & 0,01 \\
\hline $\mathrm{Be}$ & 0,88 & 0,87 & 1.2 & 0.6 \\
\hline $\mathrm{Mn}$ & 87.28 & 75,0 & 55,69 & 82,1 \\
\hline $\mathrm{Ni}$ & 25.0 & 20,0 & 17.44 & 17,0 \\
\hline $\mathrm{V}$ & 56,7 & 29,0 & 24,0 & 32,0 \\
\hline $\mathrm{Cr}$ & 78.4 & 33,0 & 21,0 & 27.0 \\
\hline Co & 7.6 & 7,5 & 10.0 & 7.2 \\
\hline $\mathrm{Pb}$ & 39.1 & 19,0 & 11.0 & 12.0 \\
\hline $\mathrm{Zn}$ & 37.2 & 11,25 & 50.0 & 26.15 \\
\hline $\mathrm{Bi}$ & 1.0 & 1,01 & 1,3 & 1.01 \\
\hline $\mathrm{Ge}$ & 1.2 & 1,87 & 6.0 & 3.4 \\
\hline $\mathrm{Ga}$ & 10.0 & 4,0 & 70.0 & 62.01 \\
\hline $\mathrm{Nb}$ & 12.3 & 10.0 & 11,0 & 10,3 \\
\hline Mo & 2.33 & 0.6 & 1.5 & 0.72 \\
\hline $\mathrm{Sn}$ & 2,5 & 1.87 & 1.5 & 1.3 \\
\hline $\mathrm{Cu}$ & 27.7 & 16,25 & 17.0 & 23,1 \\
\hline $\mathrm{Ti}$ & 1620.0 & 1500.0 & 1231,0 & 1350,0 \\
\hline $\mathrm{Zr}$ & 80.5 & 10,0 & 54,0 & +3.0 \\
\hline $\mathrm{La}$ & 10.8 & 10,0 & 10.0 & 10.0 \\
\hline Y & 10.0 & 10.0 & 12.1 & 10,0 \\
\hline $\mathrm{Yb}$ & 0.44 & 0.3 & 0.23 & 0.21 \\
\hline $\mathrm{Sc}$ & 4.1 & 2.1 & 3.2 & 4.0 \\
\hline $\mathrm{Li}$ & 42.98 & 66,25 & 110.0 & 84,0 \\
\hline $\mathrm{Sr}$ & 560.0 & 1160.0 & 300.0 & 3.0 \\
\hline $\mathrm{Ba}$ & 1116.7 & 400.0 & 410.0 & 320,0 \\
\hline $\mathrm{Ag}$ & 0.007 & 0.00125 & 0.002 & 0.003 \\
\hline
\end{tabular}




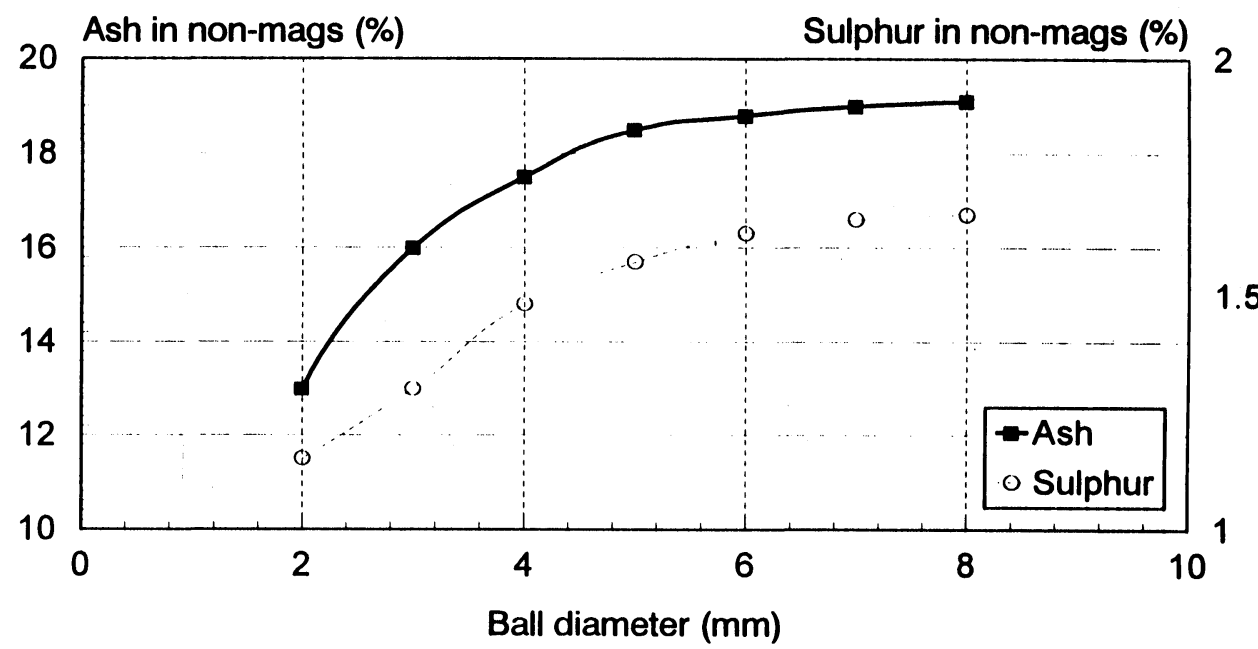

Fig. 3. The effect of the diameter of steel balls used as the matrix, on the reduction of ash and sulphur.

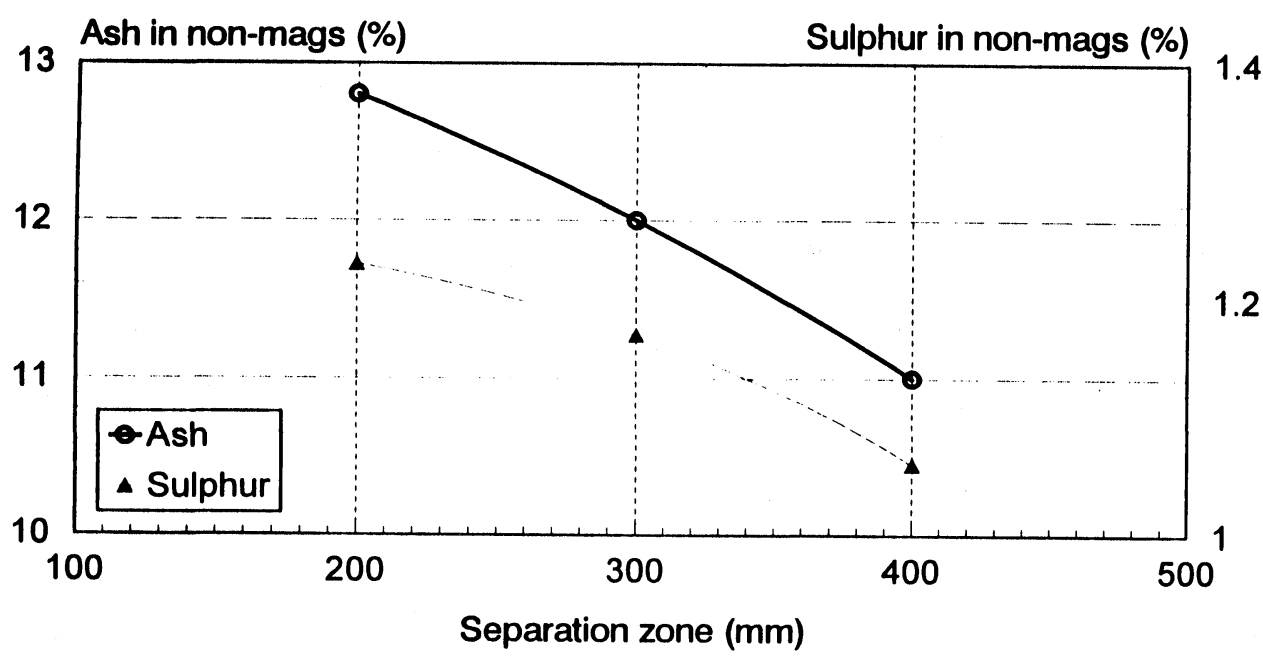

Fig. 4. The effect of the length of the separation zone on the efficiency of separation of coal. 


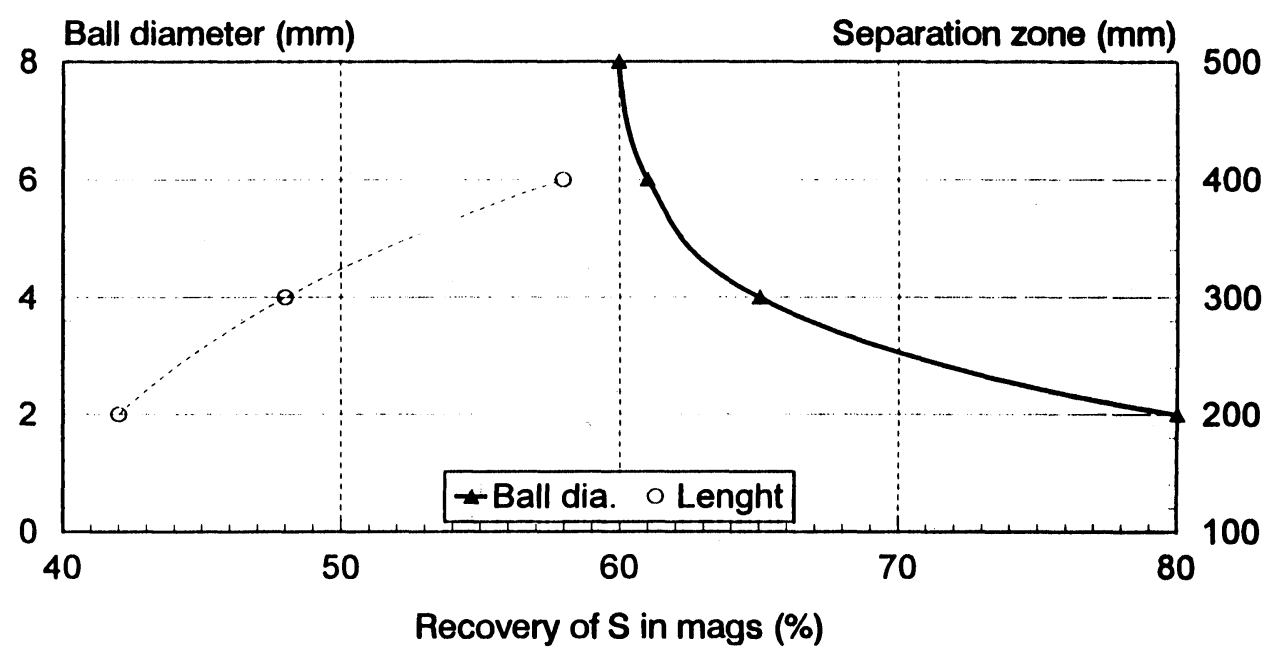

Fig. 5 Recovery of sulphur into the magnetic fraction as a function of the ball diameter and of the length of the separation zone.

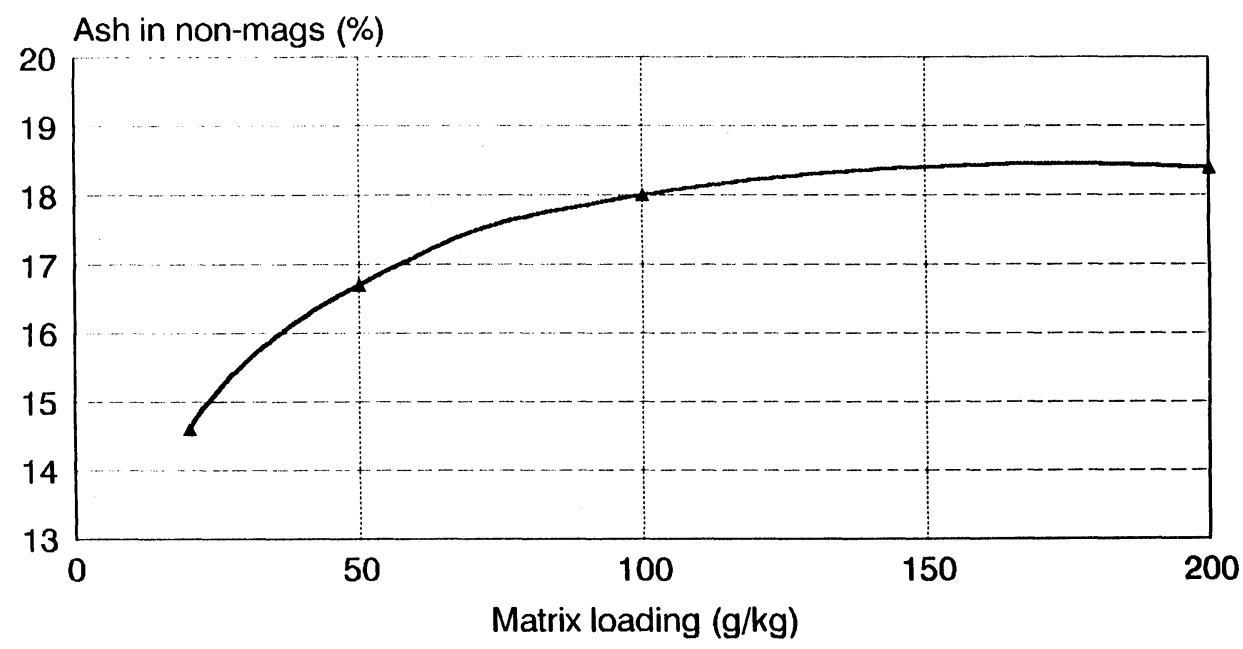

Fig. 6 The effect of matrix loading on the efficiency of magnetic beneficiation of coal.(the matrix loading is expressed in grams per $\mathrm{kg}$ of matrix mass) 
It transpired that coals of different grades could be upgraded to different degrees at different values of magnetic induction, as can be seen from Figures 7, 8 and 9 .

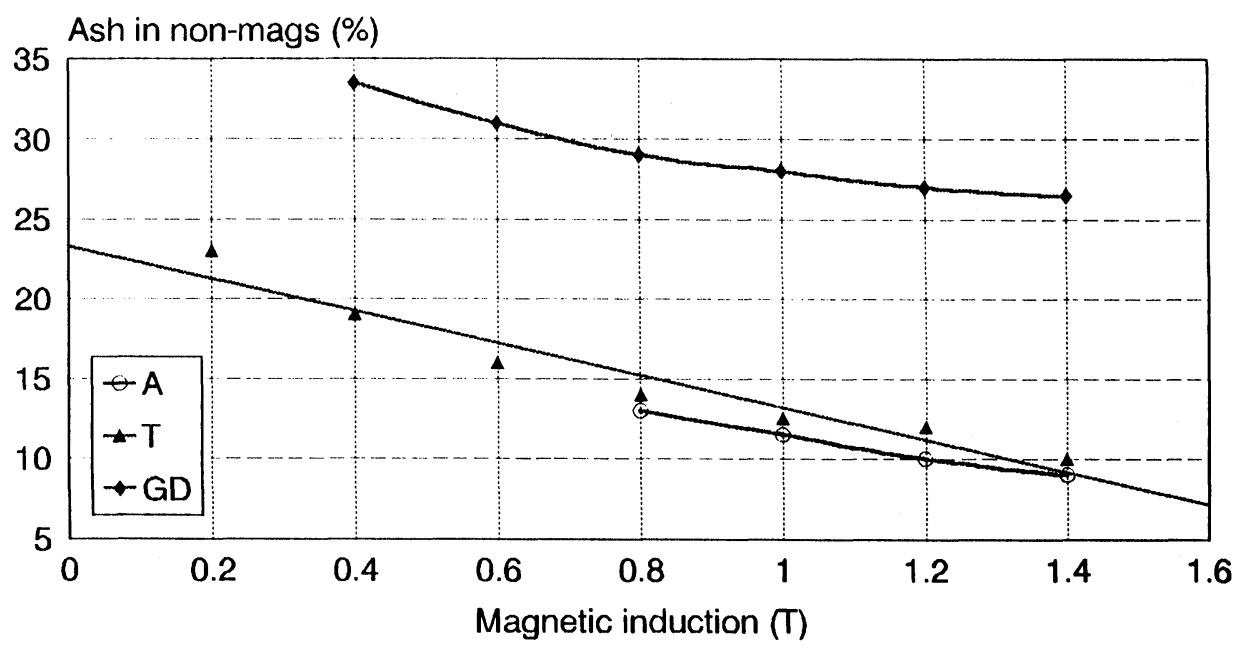

Fig. 7. The effect of the magnetic induction on the concentration of ash in the non-magnetic product, for different grades of coal.

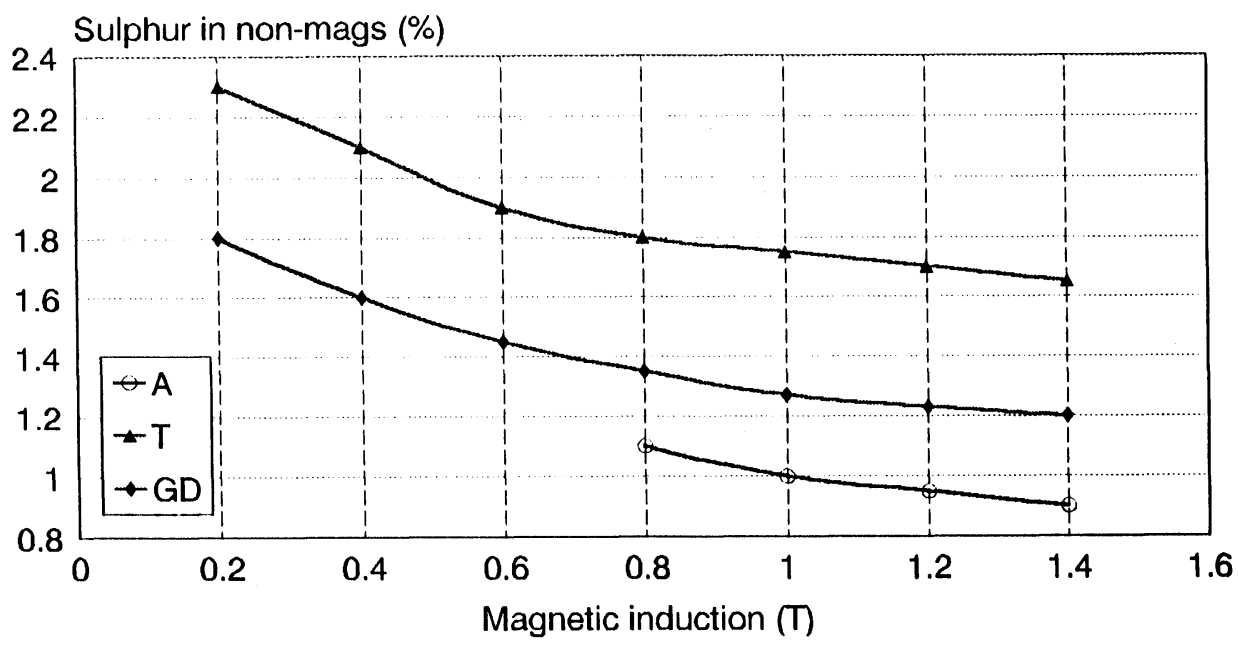

Fig. 8 The effect of magnetic induction on concentration of sulphur in the non-magnetic product 


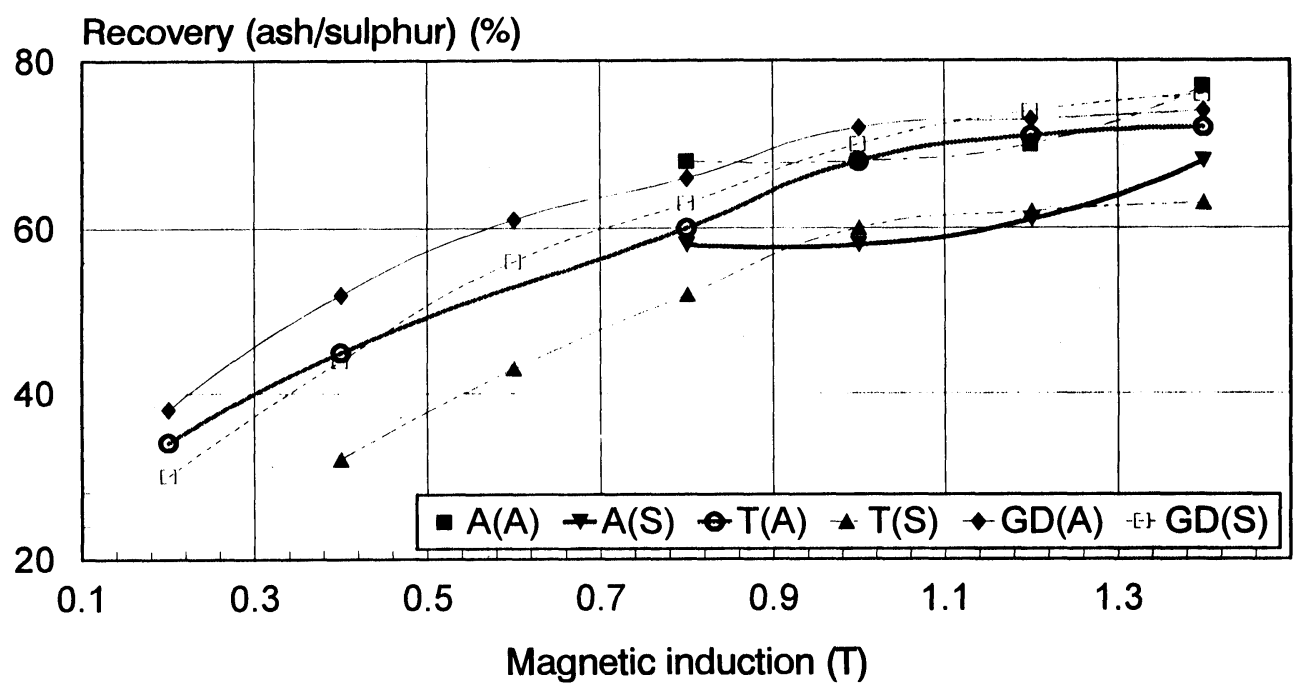

Fig. 9 The effect of the magnetic induction on the recovery of ash sulphur in the magnetic fraction, for various grades of coal

Hydrodynamic regime of the slurry flow in the working space, together with the magnetic field strength, have the decisive effect on the efficiency of the process, as can be seen in Figs. 10 and 11 .

It has been observed that expanded metal or steel balls of diameter 2 to $3 \mathrm{~mm}$ are required for wet beneficiation of finely ground coal. The tests have shown that in order to achieve optimum results of the removal of ash and sulphur, precise experimental conditions must be observed.

\section{PROPERTIES OF PRODUCTS OF MAGNETIC BENEFICIATION}

In magnetic beneficiation of coal, the magnetic fraction contains pyritic sulphur and partly organic sulphur, as a result of the capture of pyritised coal matter saturated with organic sulphur. 
Analysis of samples thus obtained has shown that HGMS is capable of removing, from the coal of all grades, 70 to $90 \%$ of pyrite, either liberated or unliberated, finely dispersed and bound in vitrinite. Carbonates report fully into the magnetic fraction, despite their negligible concentration in the feed material.

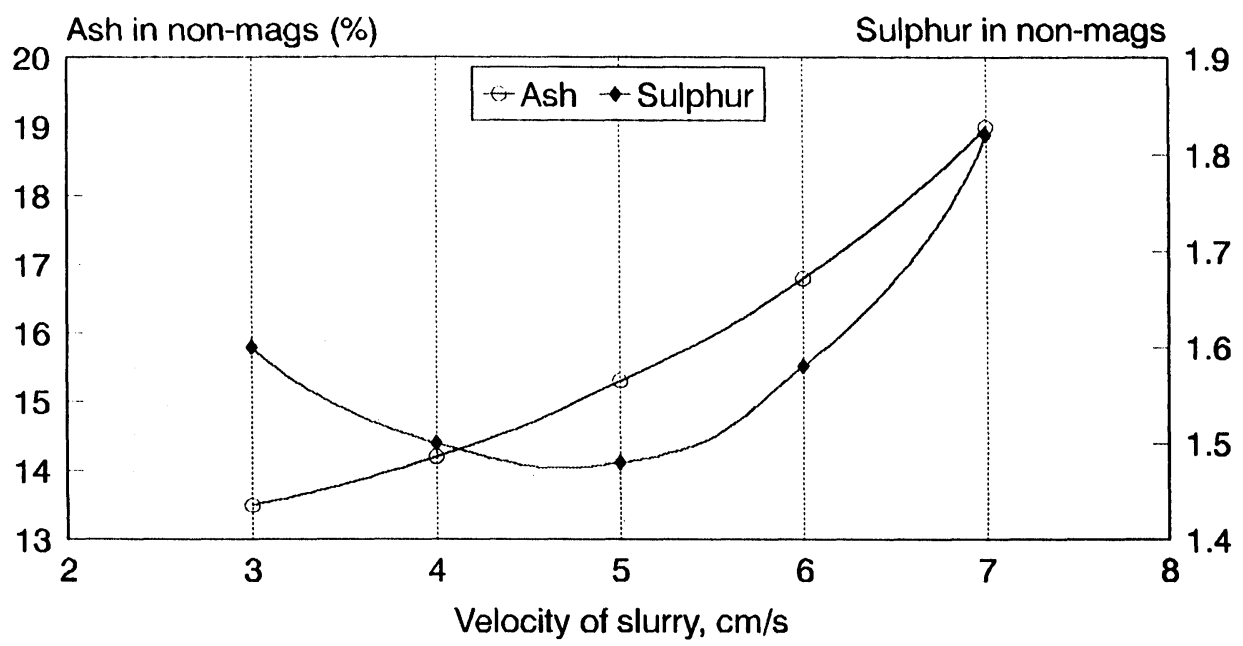

Fig. 10 The effect of velocity of the slurry on the concentration of ash and sulphur in the non-magnetic product.

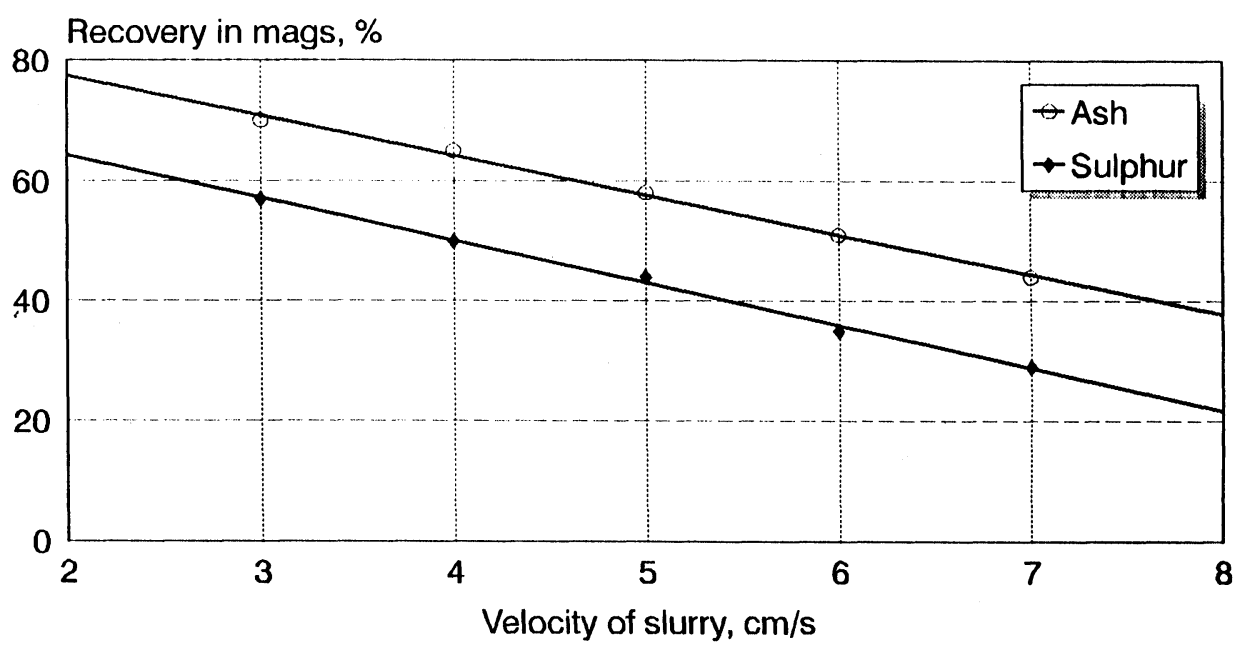

Fig. 11 The effect of the velocity of the slurry on the recovery of ash and sulphur into the magnetic fraction 
Clayey minerals and quartz report partially into the magnetic fraction, in the range from 50 to $80 \%$. With coal in early stages of metamorphism, the magnetic product has a lower yield and increased concentration of total and pyritic sulphur.

Dependence of specific magnetic susceptibility of the feed coal and of the products of magnetic separation of coal, on density and on magnetic induction, is shown in Figs. 12 and 13, respectively.

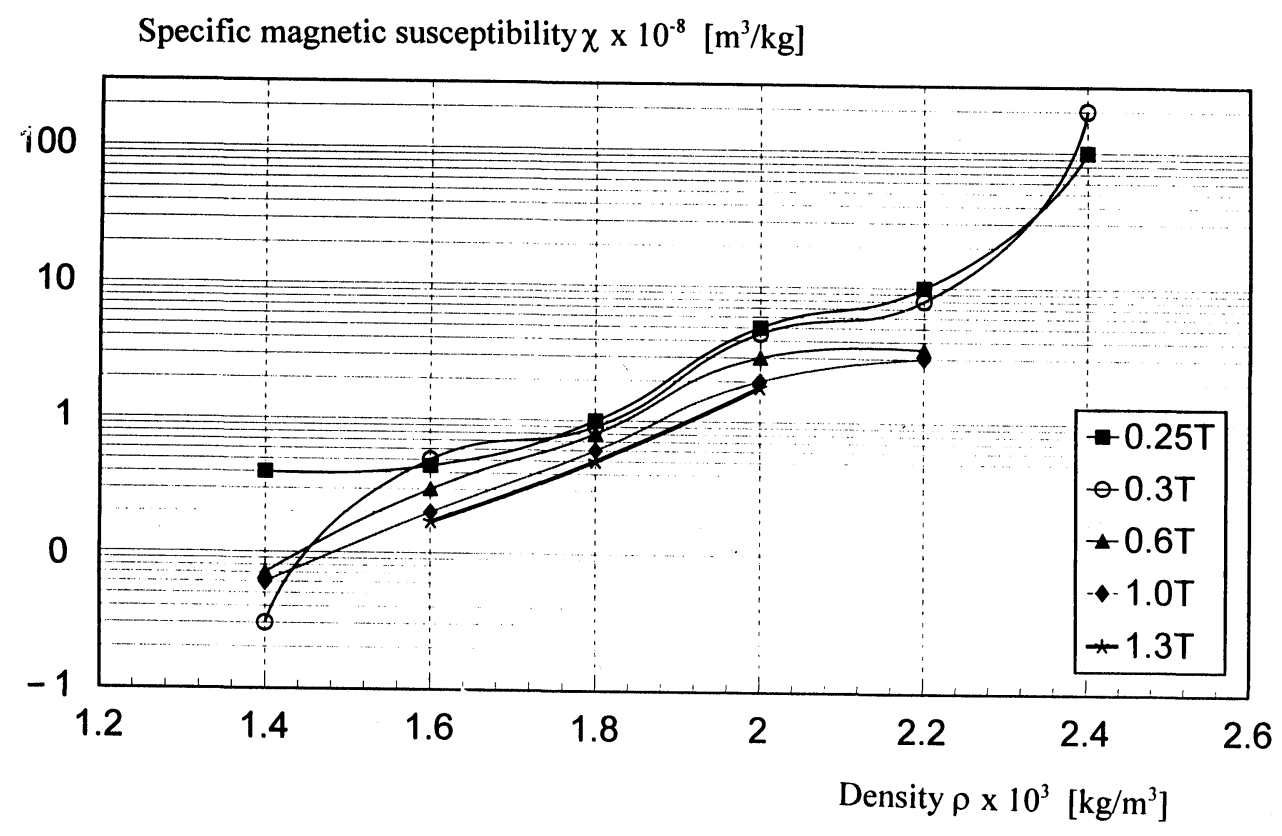

Fig. 12 Dependence of specific magnetic susceptibility of the feed coal on density, for various values of magnetic induction.

The coal of different grades contains considerable concentrations of heavy metals and of toxic and harmful elements. The following conclusions can be made from the investigation of distribution of rare and dispersed elements in steam coal, according to products of magnetic beneficiation (Tables IV and V). 


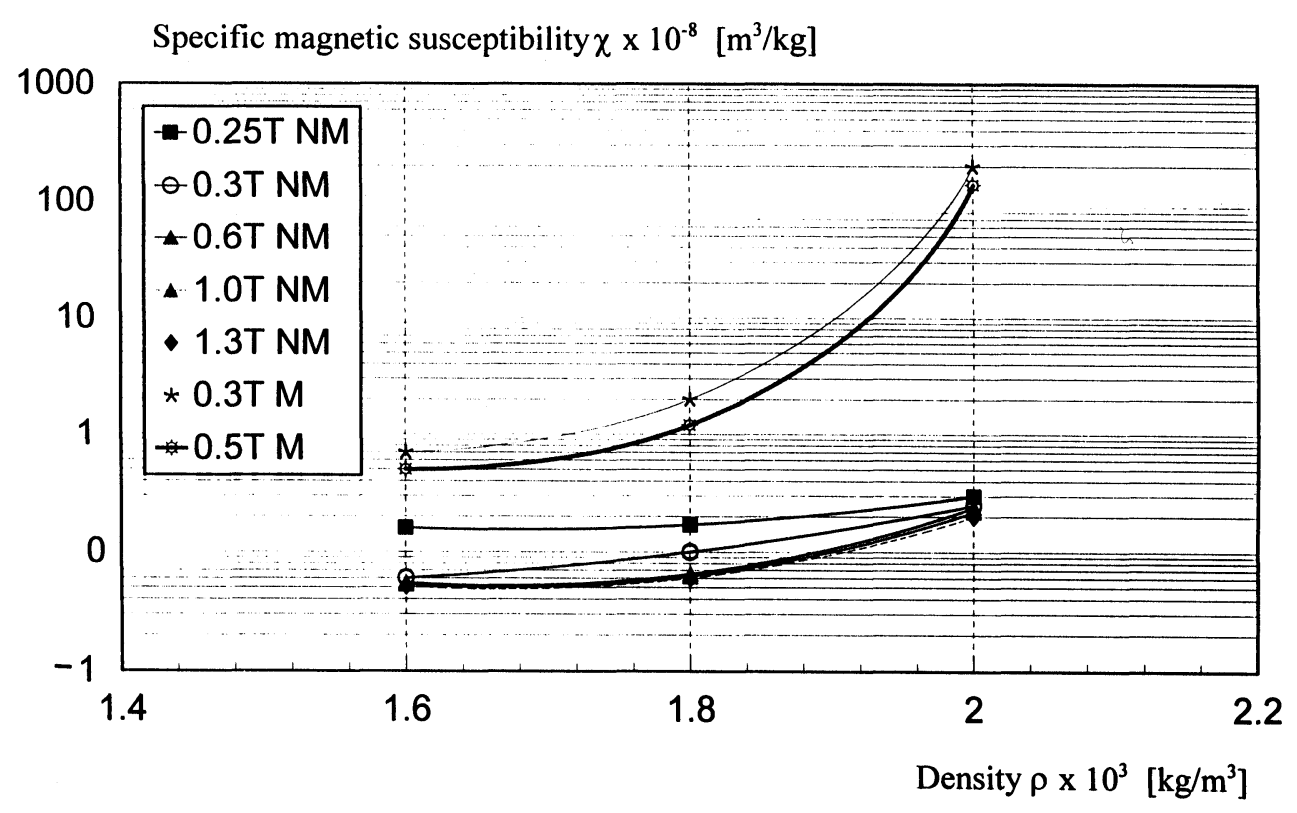

Fig. 13 Dependence of specific magnetic susceptibility of products of magnetic beneficiation of coal on density, for various values of magnetic induction.

a. Mercury which is present in all grades of coal, with the exception of $A$, is found in concentrations from 0.01 to $0.2 \mathrm{~g} / \mathrm{t}$. In the run-of-mine coal the concentration of mercury increases, is concentrated in heavy fractions and reports fully into the magnetic fraction.

b. Arsenic, nickel and manganese are confined to sulphides and report into the magnetic fractions, with recovery ranging from 50 to $80 \%$.

c. Fluorine and germanium are tied, through the valency bond, with the organic matter and remain predominantly (70 to $80 \%$ ) in the non-magnetic product. 
Table IV. Distribution of the accompanying elements in products of magnetic beneficiation of coals $\mathrm{A}$ and $\mathrm{T}$.

\begin{tabular}{|c|c|c|c|c|c|c|}
\hline \multirow[b]{2}{*}{ Element } & \multicolumn{3}{|c|}{$\mathrm{A}$} & \multicolumn{3}{|c|}{$\mathrm{T}$} \\
\hline & $\begin{array}{l}\text { Concentra- } \\
\text { tion in } \\
\text { non-mags }\end{array}$ & $\begin{array}{c}\text { Concentra- } \\
\text { tion in mags }\end{array}$ & $\begin{array}{c}\text { Recovery } \\
\text { into mags } \\
(\%)\end{array}$ & $\begin{array}{l}\text { Concentra- } \\
\text { tion in } \\
\text { non-mags }\end{array}$ & $\begin{array}{c}\text { Concentra- } \\
\text { tion in mags }\end{array}$ & $\begin{array}{c}\text { Recovery } \\
\text { into mags } \\
(\%)\end{array}$ \\
\hline As & 11.4 & 36.0 & 47,0 & - & - & - \\
\hline $\mathrm{F}$ & 117.2 & 80.0 & 14,6 & - & - & - \\
\hline $\mathrm{Be}$ & 0.71 & 0.31 & 9,8 & 1.0 & 0,5 & 14.3 \\
\hline $\mathrm{Mn}$ & 33.0 & 359.0 & 73,1 & 50.0 & 150.0 & 50.0 \\
\hline $\mathrm{Ni}$ & 20.0 & 355,8 & 81,6 & 10.0 & 50.0 & 62.5 \\
\hline V & 45.0 & 84.0 & 32,0 & 30.0 & 30.0 & 25,0 \\
\hline $\mathrm{Cr}$ & 46.0 & 124.2 & 40,3 & 15.0 & 87.0 & 65.9 \\
\hline Co & 7.7 & 18.35 & 37,3 & 5.0 & 15,0 & 50.0 \\
\hline $\mathrm{Pb}$ & 18.0 & 110.8 & 60.6 & 7.0 & 55,0 & 72.4 \\
\hline $\mathrm{Zn}$ & 200.0 & 111,4 & 12.2 & 5.0 & 30.0 & 66.7 \\
\hline $\mathrm{Bi}$ & 1.08 & 1.0 & 18,8 & 1.0 & 1.0 & 25.0 \\
\hline $\mathrm{Ge}$ & 0.7 & 1.6 & 36,1 & 2.0 & 1.5 & 20.0 \\
\hline $\mathrm{Ga}$ & 8.5 & 22.7 & 40.0 & 2.0 & 1,5 & 20,0 \\
\hline $\mathrm{Nb}$ & 12.0 & 17.4 & 26,7 & 10.0 & 10.0 & 25.0 \\
\hline Mo & 1.5 & 5.4 & 50,3 & 1.0 & 1.5 & 33.3 \\
\hline $\mathrm{Sn}$ & 2.2 & 4.0 & 31,4 & 1.5 & 3.0 & 40.0 \\
\hline $\mathrm{Cu}$ & 20.0 & 75.9 & 48.7 & 15.0 & 20.0 & 30.8 \\
\hline $\mathrm{Ti}$ & 1540.0 & 1955.2 & 20,0 & 1500.0 & 1500.0 & 25.0 \\
\hline $\mathrm{Zr}$ & 85.0 & 68.7 & 15.0 & 30.0 & 70.0 & 43.8 \\
\hline $\mathrm{La}$ & 11.0 & 10.0 & 18.5 & 10.0 & 10.0 & 25,0 \\
\hline Y & 11.0 & 10.0 & 18.5 & 10.0 & 10.0 & 25.0 \\
\hline $\mathrm{Yb}$ & 43.0 & 0.49 & 22.2 & 0.3 & 0.3 & 25.0 \\
\hline $\mathrm{Sc}$ & 60.1 & 4.1 & 14.3 & 2.0 & 3.0 & 33.3 \\
\hline $\mathrm{Li}$ & 31.0 & 59.3 & 32.4 & 55.0 & 100.0 & 37.7 \\
\hline $\mathrm{Sr}$ & 550.0 & 598.0 & 21,4 & - & - & - \\
\hline $\mathrm{Ba}$ & 920.0 & 1504.0 & 29,0 & 300.0 & 700.0 & 43.8 \\
\hline $\mathrm{Ag}$ & 0.03 & 0.0017 & 18.5 & - & - & - \\
\hline
\end{tabular}


Table V. Distribution of the accompanying elements in products of magnetic beneficiation of coals GD and D.

\begin{tabular}{|c|c|c|c|c|c|c|}
\hline \multirow[b]{2}{*}{ Element } & \multicolumn{3}{|c|}{ GD } & \multicolumn{3}{|c|}{ D } \\
\hline & $\begin{array}{l}\text { Concentra- } \\
\text { tion in } \\
\text { non-mags }\end{array}$ & $\begin{array}{l}\text { Concentra- } \\
\text { tion in mags }\end{array}$ & $\begin{array}{c}\text { Recovery } \\
\text { into mags } \\
(\%)\end{array}$ & $\begin{array}{l}\text { Concentra- } \\
\text { tion in } \\
\text { non-mags }\end{array}$ & $\begin{array}{c}\text { Concentra- } \\
\text { tion in mags }\end{array}$ & $\begin{array}{c}\text { Recovery } \\
\text { into mags } \\
(\%)\end{array}$ \\
\hline As & 14,5 & 83.0 & 80,2 & 9,5 & 33,5 & 63.2 \\
\hline $\mathrm{F}$ & 286.0 & 198.0 & 66,6 & 179,0 & 172.0 & 47,3 \\
\hline $\mathrm{Be}$ & 1.5 & 0.5 & 11.6 & 0.1 & 0,5 & 32,4 \\
\hline $\mathrm{Mn}$ & 30.0 & 150,0 & 70,0 & 30,0 & 150.0 & 71,1 \\
\hline $\mathrm{Ni}$ & 10.0 & 70,08 & 81,2 & 15,0 & 50,0 & 80.0 \\
\hline V & 20.0 & 30,0 & 29,0 & 30,0 & 50,0 & 64.4 \\
\hline $\mathrm{Cr}$ & 15.0 & 50,0 & 55,3 & 20,0 & 50.0 & 72.2 \\
\hline Co & - & 7.0 & 16,2 & - & 7.0 & 39.0 \\
\hline $\mathrm{Pb}$ & 10.0 & 20,0 & 42,2 & 5,0 & 20,0 & 65,0 \\
\hline $\mathrm{Zn}$ & 15,0 & 70.0 & 90,3 & 10,0 & 50,0 & 74,6 \\
\hline $\mathrm{Bi}$ & 1.0 & 1,0 & 17,9 & 1,0 & - & - \\
\hline Ge & 5.0 & 2.9 & 11.2 & 3,9 & 2.5 & 28.9 \\
\hline $\mathrm{Ga}$ & 65.4 & 47.6 & 15,8 & 60,0 & 51,3 & 32.4 \\
\hline $\mathrm{Nb}$ & 10.0 & 10,0 & 21.1 & 10,0 & 10.0 & 37.9 \\
\hline Mo & 5.0 & 1,0 & 26,9 & 0.5 & 2.0 & 100.0 \\
\hline $\mathrm{Sn}$ & 1.0 & 2,0 & 30.9 & 2,0 & 2,0 & 60.1 \\
\hline $\mathrm{Cu}$ & 15.0 & 30.0 & 40.9 & 20,0 & 30.0 & 50.8 \\
\hline $\mathrm{Ti}$ & 1500.0 & 1500.0 & 28.3 & 1500,0 & 1500.0 & 43,3 \\
\hline $\mathrm{Zr}$ & 70,0 & 50.0 & 21,6 & 50,0 & 50.0 & 45.3 \\
\hline $\mathrm{La}$ & - & 10.0 & 23,2 & - & - & - \\
\hline Y & 10.0 & 10.0 & 23,2 & 10,0 & 10.0 & 39.0 \\
\hline$Y b$ & 0.15 & 0.15 & 15,1 & 0.2 & 0.15 & 39.0 \\
\hline $\mathrm{Sc}$ & 2.0 & 1.5 & 10,9 & 3.0 & 2.0 & 19.5 \\
\hline $\mathrm{Li}$ & 62.0 & 130.0 & 27,4 & 75,0 & 82.0 & 32,0 \\
\hline $\mathrm{Rb}$ & 0.06 & 0.12 & 24,8 & 75,0 & 140,0 & 54.6 \\
\hline $\mathrm{Ba}$ & 100,0 & 100.0 & 23,2 & 300.0 & 200.0 & 24.6 \\
\hline $\mathrm{Ag}$ & 0.001 & 0.003 & 34,8 & 0,001 & 0.002 & 28.9 \\
\hline $\mathrm{Cs}$ & 0.005 & 0.013 & 18,8 & 6.0 & 10.0 & 55.8 \\
\hline $\mathrm{Hg}$ & - & 0.2 & 100,0 & - & 0,04 & 100.0 \\
\hline
\end{tabular}


d. Lead and cobalt which can be found in increased concentrations in coals $\mathrm{T}$ and $\mathrm{A}$ report into the magnetic fraction. The concentration of $\mathrm{Pb}$ and $\mathrm{Co}$ in coal GD is low; Co is not redistributed and the concentration of $\mathrm{Pb}$ in the magnetic product increases by a factor of 1.7 .

e. The coal A has an increased concentration of $\mathrm{Mn}, \mathrm{Ni}, \mathrm{Pb}, \mathrm{Zn}$ and $\mathrm{Cu}$. As a result of magnetic separation the concentrations of these elements in the magnetic fraction increase by a factor of 4.1 for $\mathrm{Pb}, 14.2$ for $\mathrm{Ni}, 2.8$ for $\mathrm{Pb}$, 3 for $\mathrm{Zn}$ and 2.8 for $\mathrm{Cu}$. Combustion of this product considerably increases the concentration of these elements and enables to use them in industrial extraction.

f. The magnetic fraction from coal GD contains increased concentrations of $\mathrm{Mn}$ by a factor of $2.7, \mathrm{Ni}$ by a factor of 4 , while in a low-grade coal the concentration of $\mathrm{Cr}$ increases by a factor of 2.6 and of $\mathrm{Pb}$ by a factor of 2.9 .

g. An increase in the concentration of accompanying elements in light fractions of magnetic products has been established.

\section{CONCLUSIONS}

The results of the above described investigations were used as a basis for development of magnetic and gravity-flotation-magnetic process of beneficiation of steam coal with the objective of subsequent burning of water-slurried fuel. Feasibility analysis of these processes has shown that coal purification is an order of magnitude cheaper than desulphurisation of flue gases.

\section{REFERENCES}

[1] V.I. Karmazin et al.: Investigation of wet magnetic desulphurisation of the flotation concentrate of the Mikhailovsk COF. In: Ugol' Ukrainy no. 3 (1971), 43 (in Russian)

[2] Yu.S. Mostika et.al.: Desulphurisation of steam coal by high-gradient magnetic separation. In: Proc. Conf. "Ecological Problems of Mining Industry". Moscow (1993), 143 (in Russian) 
V.I. Karmazin: For biography see Magn. Electr. Sep. 3 (1992), 90

Yu. S. Mostika: graduated from the Dnepropetrovsk Mining Institute in 1977 and in 1986 he obtained his Ph.D. degree. His main interests are the kinetics of separation of weakly magnetic minerals by HGMS during beneficiation of ores of non-ferrous metals, coal and of industrial minerals.

E.N. Savluk: graduated from the Dnepropetrovsk Mining Institute in 1977 and in 1993 she obtained her Ph.D. degree. She joined the beneficiation department in 1986 and her main interests are mineralogical analysis of coal and development of the process of magnetic desulphurisation of coal.

Keywords: high-gradient magnetic separation, coal desulphurisation, magnetic susceptibility, rare elements, toxic elements. 